\title{
Chronic lateral epicondylitis: challenges and solutions
}

This article was published in the following Dove Press journal: Open Access Journal of Sports Medicine

\section{Wilson C Lai' \\ Brandon J Erickson ${ }^{2}$ \\ Ryan A Mlynarek ${ }^{3}$ \\ Dean Wang ${ }^{4}$}

'David Geffen School of Medicine at UCLA, Los Angeles, CA, USA; ${ }^{2}$ Rothman Institute, New York, NY, USA; ${ }^{3}$ HA Orthopaedic Specialists, Ann Arbor, MI, USA; ${ }^{4}$ Department of Orthopaedic Surgery, UC Irvine Health, Orange, CA, USA
Correspondence: Dean Wang Department of Orthopaedic Surgery, UC Irvine Health, I0I The City Drive South, Pavilion III, 2nd Floor, Orange, CA 92868, USA

Email deanwangmd@gmail.com

\begin{abstract}
Lateral epicondylitis (LE) is a significant source of pain and dysfunction resulting from repetitive gripping or wrist extension, radial deviation, and/or forearm supination. Although most cases are self-limiting over several years, controversy exists regarding the best treatment strategy for chronic LE. Nonsteroidal anti-inflammatory drugs (NSAIDs), physical therapy (PT), shockwave therapy, and injections with corticosteroids or biologics are all conservative treatment options for LE. For refractory cases, surgical options include open, arthroscopic, and percutaneous techniques. In this review, the current evidence behind these treatment strategies is presented. The data demonstrate that NSAIDs, PT, bracing, and shockwave therapy provide limited benefit for treating LE. Biologics such as platelet-rich plasma and autologous whole-blood injections may be superior to steroid injections in the long-term management of LE. Although the initial results are promising, larger comparative studies on stem cell injections are needed. For refractory LE, open, arthroscopic, and percutaneous techniques are all highly effective, with no method seemingly superior over another. Arthroscopic and percutaneous approaches may result in faster recovery and earlier return to work.
\end{abstract}

Keywords: lateral epicondylitis, tennis elbow, shockwave, injection, biologics, platelet-rich plasma, stem cells, surgery

\section{Introduction}

Lateral epicondylitis (LE), or tennis elbow, affects $1 \%-3 \%$ of the general population each year. ${ }^{1-3}$ It is estimated that about 1 million people in the US develop new-onset LE annually. ${ }^{4}$ LE can cause significant pain and functional impairment, and despite its relatively high prevalence, there remains a myriad of treatments due to the lack of a single gold standard solution. LE produces a heavy socioeconomic burden resulting from lost workdays and may cause an inability to work for several weeks in some patients. ${ }^{5}$ Taylor and Hannafin reported that medial epicondylitis and LE accounted for $11.7 \%$ of work-related injury claims, resulting in an average direct workers' compensation cost of $\$ 6,593$ per case. ${ }^{6}$

\section{Epidemiology, pathogenesis, and natural history}

LE most commonly affects adults in the fourth and fifth decade of life with men and women equally affected. ${ }^{7}$ Demographic risk factors for LE include increased age or body mass index, history of rotator cuff disease, de Quervain's disease, carpal tunnel syndrome, and oral corticosteroid use, prior smoking history, and low social support. ${ }^{8,9}$ LE is commonly associated with overuse injury and strain from activities involving 
repetitive gripping or wrist extension, radial deviation, and/ or forearm supination. ${ }^{10}$ These activities lead to microtearing most commonly at the origin of the extensor carpi radialis brevis (ECRB) tendon. LE, or tennis elbow, is a common problem among adults, and despite its name, only $5 \%-10 \%$ of patients presenting with "tennis elbow" play tennis. ${ }^{11}$ The most likely pathogenesis of LE is believed to be angiofibroblastic hyperplasia, characterized by Nirschl as a degenerative process in which the tendons manifest abundant fibroblastic activity, vascular hyperplasia, and unstructured collagen fibers. ${ }^{12,13}$ Rather than an inflammatory response, it is theorized that epicondylitis results from an aborted healing response to repetitive microtrauma along with vascular deprivation at the tendon origin. The degree of angiofibroblastic infiltration also appears to correlate with pain and duration of symptoms. ${ }^{14,15}$ Patients may present with a sensation of burning over the humeral insertion of the common extensor tendons. Other symptoms include loss of grip strength and pain during daily activities, such as grasping objects, turning doorknobs, and shaking hands. ${ }^{6,16}$ The majority of LE cases are self-limiting, with about $80 \%$ of patients reporting symptomatic improvement or resolution at 1 year. ${ }^{17,18}$ However, manual labor, dominant arm involvement, longer duration of symptoms with high baseline pain levels, and poor coping mechanisms are associated with a poorer prognosis. ${ }^{17}$ It is estimated that $3 \%-11 \%$ of patients eventually require operative intervention for resistant symptoms. ${ }^{19-21}$ Knutsen et al found in a multivariate model that history of prior injection, prior orthopedic surgery, workers' compensation claim, presence of radial tunnel syndrome, and symptoms greater than 1 year were predictors of surgical treatment. ${ }^{22}$

\section{Nonoperative treatment}

Nonsurgical treatments are recommended for the initial management of acute LE and include rest, nonsteroidal anti-inflammatory drugs (NSAIDs), physical therapy (PT), shockwave therapy, braces, and steroid injections. Newer biologic treatments, such as platelet-rich plasma (PRP), autologous whole-blood injections (ABIs), and stem cell therapy, are being increasingly utilized for the nonoperative treatment of LE.

\section{NSAIDs and PT}

Although NSAIDs and PT are often employed as the first-line treatment of LE, the long-term efficacy of these interventions has not been established. In a review of 15 trials by Pattanittum et al, the authors found low-quality evidence showing that topical NSAIDs were more effective than placebo alone in the short term for reducing pain, whereas the evidence on oral NSAIDs was conflicting. ${ }^{23}$ They concluded that there are limited data on the effectiveness of treating LE with topical or oral NSAIDs.

For the management of LE with PT, Park et al examined 31 patients with LE and found improvement in visual analog scale (VAS) pain scores with PT isometric strengthening exercises compared to no PT at 1 month follow-up. ${ }^{24}$ However, no differences were observed at longer follow-up $(3,6$, and 12 months). Peterson et al found that in 81 patients with chronic LE lasting more than 3 months, PT resulted in faster regression of pain at 3 months follow-up than in patients who did not receive $\mathrm{PT} .{ }^{25}$ However, patients were not blinded to the treatment, introducing potential bias. Coombes et al also demonstrated greater complete recovery at 4 weeks follow-up in LE patients receiving PT and placebo injection compared to those receiving placebo injection alone. ${ }^{26}$ The PT group also used less analgesics or anti-inflammatory medication at 1 year follow-up. ${ }^{26}$ Smidt et al also found that improvement with PT at 1 year follow-up was slightly better than benign neglect in a randomized controlled trial (RCT), but this difference was not statistically significant. ${ }^{27}$ In a large systemic review of 23 RCTs by Smidt et al, the authors concluded that there is insufficient evidence for most PT interventions for LE due to contradicting results or insufficient power in most studies. ${ }^{28}$ Overall, while there are some data supporting the use of PT for LE in the short term, most studies show no advantage of PT for LE in the long term.

\section{Braces/orthoses}

Commonly used braces for the treatment of LE include counterforce braces with a proximal forearm strap and wrist extension splint. The compressive force of the forearm strap limits expansion and force generated by the extensors, and the extension splint helps to relax the extensor tendons. ${ }^{29}$ Struijs et al observed that forearm straps alone improved daily activities at 6 weeks compared to PT or combination in 180 patients in an RCT, but no difference was observed at 6 months or 1 year. ${ }^{30}$ Luginbühl et al randomized 29 patients with LE into three treatment groups: forearm strap, strengthening exercises, and both. ${ }^{31}$ Although they noted significant symptomatic improvement in all groups over time, they found no superiority in treatment among groups at 1 year follow-up.

\section{Shockwave therapy}

Shockwave therapy has been proposed to promote tissue healing and have an analgesic effect by stimulating nerve 
fibers. ${ }^{32}$ In two RCTs, Rompe and Pettrone and Mccall found enhanced improvements in pain and function with shockwave therapy in patients suffering from refractory LE. ${ }^{33,34}$ However, the majority of other RCTs found no difference in outcome between shockwave therapy and placebo groups. ${ }^{32,35-38}$ In a large systematic review, Sims et al concluded that shockwave therapy may be no more effective than placebo. ${ }^{29}$

\section{Corticosteroid injection}

There are abundant data demonstrating the short-term efficacy of corticosteroid injections for the treatment of LE, but no data exist regarding their long-term efficacy. Hay et al showed that at 4 weeks, $92 \%$ of patients experienced improved or complete pain relief after a corticosteroid injection compared to $57 \%$ with naproxen only. ${ }^{18}$ However, no differences were found between the two groups at 1 year. Smidt et al compared the long-term outcomes after treatment with corticosteroid injection, PT, or no treatment in an $\mathrm{RCT}^{27}$ They found that steroid injections and PT were more effective than no treatment before 6 weeks follow-up; however, corticosteroid injections were associated with worse outcomes at 1 year, which correlates with other reports. ${ }^{26,39}$ In a large systemic review of 10 trials by Krogh et al, the authors concluded that corticosteroid injections were no more effective than placebo beyond 8 weeks. ${ }^{40}$ One RCT found that the short-term benefits of corticosteroid injection were paradoxically reversed after 6 weeks, with high recurrence rates of $72 \%$ at 1 year compared to $8 \%$ after PT. ${ }^{41}$ Other RCTs have compared a combination of local anesthetic and corticosteroid to local anesthetic alone with conflicting results. ${ }^{42,43}$ Newcomer et al found improved VAS pain scores in the corticosteroid group between 2 and 6 months, whereas Lindenhovius et al found no difference in outcomes at 1 or 6 months follow-up. ${ }^{42,43}$ Overall, the possibility of worse long-term outcomes with corticosteroid injections, which may be attributed to weakening of the tendon, as well as the self-limiting nature of LE, has led some authors to discourage the use of corticosteroid injection for management of LE. ${ }^{40,44,45}$ Hence, while it seems steroid injections are effective in relieving pain from LE in the short term, there appears to be no long-lasting benefit, with a potential detriment at 1 year compared to PRP and other modalities. More research is needed on the long-term effectiveness of combined corticosteroid injection and PT.

\section{Botulinum toxin injection}

Botulinum toxin injections may help with LE by causing temporary paralysis to the extensors, preventing further microtrauma to the ECRB origin, and allowing the pathologic tissue to heal. ${ }^{46}$ Krogh et al reviewed four trials using botulinum toxin for LE and found marginal benefit compared to placebo, although all the studies were subjected to substantial bias and reported some cases of concomitant temporary paralysis of finger extension. ${ }^{40}$ Overall, the current evidence on the use of botulinum toxin is insufficient, and more studies on the optimal dosing and administration are needed.

\section{Biologics \\ PRP}

PRP is composed of concentrated platelets and growth factors that may induce a local healing response through cell recruitment, angiogenesis, and proliferation, although the precise mechanism remains unclear. ${ }^{47}$ Table 1 illustrates 17 RCTs comparing PRP injections to alternative treatments for $\mathrm{LE} .{ }^{48-63}$ In a recent review of RCTs by Chen et al, the authors found that at both short-term and long-term follow-up, patients suffering from LE reported decreased VAS pain scores after PRP injections compared to controls. ${ }^{64}$ The authors concluded that PRP injections caused no significant adverse events and may result in better pain relief compared to alternative treatments. In contrast, an older review by de Vos et al found that the majority of studies showed no additional benefit of PRP compared to controls. ${ }^{65}$ Limitations of this study were the inclusion of a small number of studies and effect size.

PRP injection has been shown to be effective in managing chronic LE in the intermediate and long term. A recent study by Seetharamaiah et al found improved VAS pain scores for the PRP injection group at 3 and 6 months follow-up compared to the normal saline group, as well as improved pain scores at 6 months compared to the triamcinolone group. ${ }^{48}$ In 230 patients with symptoms for at least 3 months, Mishra et al reported that PRP treatment resulted in improved pain scores in $71.5 \%$ of patients compared to $56.1 \%$ in the control group at 24 weeks. ${ }^{66}$ In a systematic review, Ben-Nafa and Munro found PRP injections resulted in a more gradual pain relief that continued long term compared to corticosteroid injection. ${ }^{67}$ This may be due to the fact that PRP stimulates an inflammatory response and may enhance biologic healing of the diseased tendon, whereas corticosteroid can result in further degeneration of the tissue. Krogh et al showed that steroid injection decreased tendon thickness while PRP increased tendon thickness at 3 months follow-up. ${ }^{40}$ Although many RCTs suggest a short-term advantage with the use of corticosteroid injections compared to PRP injections, PRP injections appear to be a superior long-term treatment with benefits lasting up to 2 years or greater. ${ }^{61}$ 
Table I RCTs comparing PRP injections to alternative treatments for lateral epicondylitis

\begin{tabular}{|c|c|c|c|c|c|c|}
\hline Author & Year & Journal & Patients & $\begin{array}{l}\text { Mean } \\
\text { age }\end{array}$ & Compared to & Outcome in pain scores \\
\hline $\begin{array}{l}\text { Seetharamaiah } \\
\text { et } \mathrm{al}^{48}\end{array}$ & 2017 & $\begin{array}{l}\text { Indian Journal of } \\
\text { Orthopedics }\end{array}$ & 80 & $20-40$ & NS or triamcinolone & $\begin{array}{l}\text { PRP better than steroids at } 6 \text { months. No } \\
\text { difference at } 3 \text { months. Both better than } \\
\text { NS group }\end{array}$ \\
\hline Montalvan et al ${ }^{49}$ & 2016 & Rheumatology & 25 & 47 & NS & PRP same as NS at 6 and 12 months \\
\hline Palacio et $\mathrm{al}^{50}$ & 2016 & $\begin{array}{l}\text { Revista Brasileira de } \\
\text { Ortopedia }\end{array}$ & 60 & 46 & $\begin{array}{l}0.5 \% \text { neocaine or } \\
\text { dexamethasone }\end{array}$ & $\begin{array}{l}\text { PRP same as alternative treatments at } \\
90 \text { and } 180 \text { days }\end{array}$ \\
\hline Behera et $\mathrm{al}^{51}$ & 2015 & $\begin{array}{l}\text { Journal of Orthopedic } \\
\text { Surgery }\end{array}$ & 25 & 38 & Bupivacaine & $\begin{array}{l}\text { PRP worse than bupivacaine at I month but } \\
\text { superior at } 6 \text { months and I year }\end{array}$ \\
\hline Gautam et $\mathrm{al}^{52}$ & 2015 & $\begin{array}{l}\text { Journal of Orthopedic } \\
\text { Surgery }\end{array}$ & 30 & $18-60$ & Corticosteroid & $\begin{array}{l}\text { PRP superior to steroids at } 6 \text { months. No } \\
\text { difference at } 3 \text { months }\end{array}$ \\
\hline $\begin{array}{l}\text { Lebiedziński } \\
\text { et } \mathrm{al}^{53}\end{array}$ & 2015 & International Orthopedics & 99 & 50 & $\begin{array}{l}\text { Betamethasone with } \\
\text { lidocaine }\end{array}$ & $\begin{array}{l}\text { PRP worse than steroid group at } 6 \text { weeks } \\
\text { and } 6 \text { months, but better at I year }\end{array}$ \\
\hline Tetschke et $\mathrm{al}^{54}$ & 2015 & $\begin{array}{l}\text { American Journal of Physical } \\
\text { Medicine \& Rehabilitation }\end{array}$ & 52 & 52 & Laser & $\begin{array}{l}\text { Laser application and PRP therapy were } \\
\text { both effective in treating LE }\end{array}$ \\
\hline Yadav et $\mathrm{al}^{55}$ & 2015 & $\begin{array}{l}\text { Journal of Clinical and } \\
\text { Diagnostic Research }\end{array}$ & 60 & 37 & Methylprednisone & $\begin{array}{l}\text { PRP group worse than steroids at I } 5 \text { days } \\
\text { and I month while PRP significantly better } \\
\text { at } 3 \text { months }\end{array}$ \\
\hline Mishra et $\mathrm{al}^{56}$ & 2014 & $\begin{array}{l}\text { American Journal of Sports } \\
\text { Medicine }\end{array}$ & 230 & 48 & Bupivacaine & $\begin{array}{l}\text { PRP same as bupivacaine at } 12 \text { weeks. PRP } \\
\text { superior at } 24 \text { weeks }\end{array}$ \\
\hline Raeissadat et $\mathrm{al}^{58}$ & 2014 & $\begin{array}{l}\text { Pain Research and } \\
\text { Treatment }\end{array}$ & 40 & 46 & $\begin{array}{l}\text { Autologous whole } \\
\text { blood }\end{array}$ & $\begin{array}{l}\text { PRP same as whole blood at } 4 \text { weeks, } \\
\text { however PRP superior at } 8 \text { weeks }\end{array}$ \\
\hline Raeissadat et $\mathrm{al}^{57}$ & 2014 & $\begin{array}{l}\text { BMC Sports Science, } \\
\text { Medicine and Rehabilitation }\end{array}$ & 67 & 44 & $\begin{array}{l}\text { Autologous whole } \\
\text { blood }\end{array}$ & $\begin{array}{l}\text { PRP same as whole blood at } 4 \text { and } 8 \text { weeks, } \\
\text { and } 6 \text { and } 12 \text { months }\end{array}$ \\
\hline Omar et al ${ }^{59}$ & 2012 & $\begin{array}{l}\text { The Egyptian } \\
\text { Rheumatologist }\end{array}$ & 30 & 38 & Steroid & PRP same as steroids at 6 weeks \\
\hline Creaney et $\mathrm{al}^{60}$ & 2011 & $\begin{array}{l}\text { British Journal of Sports } \\
\text { Medicine }\end{array}$ & 150 & 53 & $\begin{array}{l}\text { Autologous whole } \\
\text { blood }\end{array}$ & PRP same as whole blood at 6 months \\
\hline Gosens et $\mathrm{al}^{61}$ & 2011 & $\begin{array}{l}\text { American Journal of Sports } \\
\text { Medicine }\end{array}$ & 100 & 47 & Corticosteroid & $\begin{array}{l}\text { PRP worse at } 4 \text { weeks, but superior at } \\
26 \text { weeks, I and } 2 \text { years follow-up. No } \\
\text { difference at } 8 \text { and } 12 \text { weeks }\end{array}$ \\
\hline Thanasas et $\mathrm{al}^{62}$ & 2011 & $\begin{array}{l}\text { American Journal of Sports } \\
\text { Medicine }\end{array}$ & 28 & 36 & $\begin{array}{l}\text { Autologous whole } \\
\text { blood }\end{array}$ & $\begin{array}{l}\text { PRP superior at } 6 \text { weeks, no difference at } \\
3 \text { or } 6 \text { months }\end{array}$ \\
\hline $\begin{array}{l}\text { Peerbooms } \\
\text { et } \mathrm{al}^{63}\end{array}$ & 2010 & $\begin{array}{l}\text { American Journal of Sports } \\
\text { Medicine }\end{array}$ & 100 & 47 & Corticosteroid & $\begin{array}{l}\text { PRP group initially worse compared to } \\
\text { steroids, however superior at } 6 \text { months and } \\
\text { I year. No differences at I, } 2 \text {, or } 3 \text { months }\end{array}$ \\
\hline
\end{tabular}

Abbreviations: LE, lateral epicondylitis; NS, normal saline; PRP, platelet-rich plasma; RCTs, randomized controlled trials.

A recent study also showed that PRP injections may even reduce the need for surgical intervention. ${ }^{68}$ This has important cost-saving implications as the surgical cost for LE is estimated to be between $\$ 10,000$ and $\$ 12,000 .{ }^{56}$ In a prospective RCT, Merolla et al found that PRP and arthroscopic debridement had similar effectiveness in the short and medium term; however, surgery resulted in better pain and grip strength recovery at 2 years. ${ }^{69}$ Because of the heterogeneity of PRP formulations among commercial systems, as well as the high degree of intersubject and intrasubject variability in the PRP composition produced, ${ }^{70}$ much more work is needed to determine the optimal PRP formulation (eg, high or low leukocyte concentration) that is effective in providing long-term pain relief in chronic LE.
$A B I$

$\mathrm{ABI}$ has been shown to be beneficial in the treatment of LE. Much like PRP, whole blood contains growth factors and cellular mediators that are thought to increase vascularity and promote healing. Another rationale for $\mathrm{ABI}$ is that it may induce a local pro-inflammatory response in the diseased area to promote healing. ${ }^{71}$ Some studies reported that $\mathrm{ABI}$ and PRP injections are equally effective in improving pain scores compared to controls..$^{57,60,62}$ However, Raeissadat et al and Thanasas et al found that PRP injections were more efficacious than ABI at 8 weeks and 6 weeks, respectively, in decreasing VAS pain scores. ${ }^{58,62}$ The results have led Thanasas et al to conclude that PRP injection is superior to ABI for the short-term treatment of chronic or refractory LE. ${ }^{62}$ 
Higher concentrations of growth factors in PRP compared with whole blood may explain these clinical differences. ${ }^{72}$ In a review of nine RCTs by Chou et al, the authors found that $\mathrm{ABI}$ was more effective than corticosteroid injections in relieving pain, but it was not more effective than PRP. ${ }^{73}$

\section{Stem cells}

Stem cell therapy has been investigated as a treatment option for chronic LE. In a small study of 12 patients with chronic LE, Lee et al found that injection of allogeneic adiposederived mesenchymal stem cells progressively improved VAS scores for up to the study's end point at 52 weeks with no adverse events reported. ${ }^{74}$ In another pilot study of 12 patients, Connell et al demonstrated that an injection consisting of collagen-producing tenocyte-like cells derived from autologous skin fibroblasts resulted in clinical improvement and increased tendon thickness. ${ }^{75}$ Clinical improvement was observed in Patient-Rated Tennis Elbow Evaluation (PRTEE) scores at 6 weeks, 3 months, and 6 months compared to baseline, and increased thickness in tendon structure was noted on ultrasound. ${ }^{75}$ Of the 12 patients, 11 (91.6\%) expressed satisfaction, and $10(83.3 \%)$ noted that they would undergo the procedure again if needed. Similar findings were reported by Wang et al using autologous tenocytes derived from patellar tendon cells in a cohort of 16 patients with refractory LE. ${ }^{76}$ At 1 month, 3 months, 6 months, and 1 year, patients reported significantly decreased VAS pain scores, and magnetic resonance imaging showed improved tendon structure at the common extensor tendon origin. In another study, Singh et al used a bone marrow aspirate containing both PRP and mesenchymal stem cells in the treatment of LE in 30 patients. ${ }^{77}$ The authors found improved PRTEE scores at 2,6 , and 12 weeks after treatment. Overall, stem cell therapy may be an effective tool for patients, especially for those who have failed nonoperative treatment. However, comparative studies with larger study populations and long-term follow-up are needed before further conclusions can be drawn.

\section{Surgical treatment}

Surgical treatment is typically reserved for patients who experienced failure after 6-12 months of nonoperative treatment. It involves debridement of the diseased tissue within the ECRB and occasionally, the extensor digitorum communis, through open, arthroscopic, or percutaneous techniques. Controversy exists regarding the best surgical approach for treating LE. Nirschl et al were the first to report a success rate of $97.7 \%$ in 82 patients who underwent an open surgical excision and repair of the diseased ECRB along with decortication of the underlying bone. ${ }^{13}$ Other approaches have since been described. Using the American Board of Orthopaedic Surgery database, Wang et al reported that $92.2 \%$ and $7.8 \%$ of open and arthroscopic surgeries, respectively, were performed for LE patients by newly trained orthopedic surgeons. ${ }^{78}$ Percutaneous tenotomy, debridement only, and debridement with tendon repair comprised $6.4 \%, 46.3 \%$, and $47.3 \%$ of open treatment, respectively.

\section{Open approach}

The Nirschl procedure describes excision of the area of angiofibroblastic hyperplasia and release of the common extensor origin (Figure 1). Numerous studies have demonstrated the efficacy and safety of open procedures for the treatment of LE. ${ }^{79-82}$ Dwyer et al found that greater than $95 \%$ of LE patients reported satisfaction with the open approach at 2 years follow-up. ${ }^{82}$ Dunn et al demonstrated sustained high long-term satisfaction rates for 44 patients, with a $97 \%$ improvement rate and a 3\% rate of revision at an average of 12.6 years of follow-up after surgery. ${ }^{81}$ These studies support the findings that an open surgical approach is highly

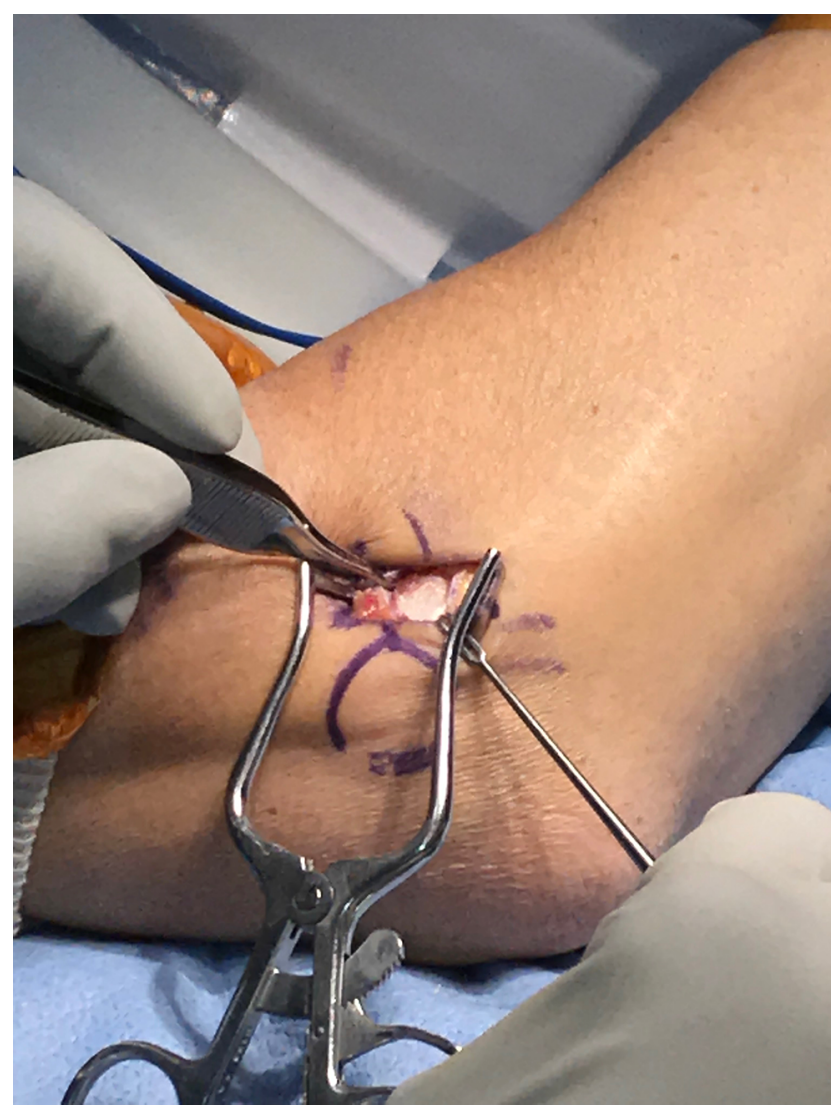

Figure I Open approach for the debridement of diseased ECRB tendon. Abbreviation: ECRB, extensor carpi radialis brevis. 
effective for treating refractory LE cases. Thornton et al described the addition of suture anchor repair of the ECRB tendon to the lateral epicondyle and reported increased grip and pinch strengths of $110 \%$ and $106 \%$, respectively, when compared with the nonoperative limb. ${ }^{83}$ In contrast, a recent RCT by Kroslak and Murrell found no additional benefit of surgical excision of the diseased portion of ECRB over placebo surgery in a cohort of 26 patients. ${ }^{84}$ The authors believed that these findings may be attributed to stimulation of healing in the area, local denervation, passage of time, or the Hawthorne effect.

\section{Arthroscopic approach}

Benefits of the arthroscopic approach include direct visualization of the joint and ability to address concomitant intraarticular abnormalities. Baker et al performed 42 arthroscopic surgeries for LE and reported a 95\% improvement at 34 months follow-up. ${ }^{85}$ At a mean of 130 months after surgery, VAS scores remained at 0 , suggesting that the long-term benefits of arthroscopic release are sustained over time. Many studies comparing open to arthroscopic treatment have shown no significant differences in pain or function scores (Table 2). ${ }^{86-89}$ However, Peart et al reported in a cohort of 87 patients that those treated arthroscopically were able to return to work sooner. ${ }^{89}$ In a large review, Karkhanis et al found that the arthroscopic approach had a lower failure rate and enabled earlier return to activity compared to open techniques. ${ }^{90}$ In one of the largest comparative studies involving 305 patients, Solheim et al found that arthroscopic treatment resulted in a small improvement in QuickDASH (Disabilities of the arm, Shoulder and Hand) score compared to open treatment. Overall, the small number of comparative studies suggest that open and arthroscopic techniques are comparable and highly effective for treating chronic LE.

\section{Percutaneous approach}

Percutaneous treatment of LE has also demonstrated good results. In the study of Grundberg and Dobson, 29 out of 32 patients reported good or excellent results at an average of 26 months after surgery, with magnitude of grip strength improving 60\%-90\%. ${ }^{91}$ Dunkow et al reported greater improvement in DASH scores, patient satisfaction, and earlier return to activity in the percutaneous group compared to the open group..$^{92}$ Othman compared arthroscopic vs percutaneous approach and found no difference in pain relief, patient satisfaction, or time to return to work at 1 year follow-up. ${ }^{93}$ These findings are consistent to those of Szabo et al who found no differences in recurrence rate, complication rate,

Table 2 Studies comparing open, arthroscopic, and percutaneous approaches for surgical treatment of LE

\begin{tabular}{|c|c|c|c|c|c|c|}
\hline Authors & Year & Journal & Patients & Comparisons & $\begin{array}{l}\text { Duration of } \\
\text { follow-up } \\
\text { postsurgery }\end{array}$ & Conclusions \\
\hline Kwon et al ${ }^{86}$ & 2017 & $\begin{array}{l}\text { Journal of Shoulder } \\
\text { Elbow Surgery }\end{array}$ & 55 & $\begin{array}{l}\text { Open vs } \\
\text { arthroscopic }\end{array}$ & 30 months & $\begin{array}{l}\text { No significant differences in DASH and } \\
\text { VAS scores between groups. Open Nirschl } \\
\text { technique provides slightly superior pain } \\
\text { relief during hard work }\end{array}$ \\
\hline Solheim et $\mathrm{a}^{87}$ & 2013 & Arthroscopy & 305 & $\begin{array}{l}\text { Open vs } \\
\text { arthroscopic }\end{array}$ & $\begin{array}{l}\text { Minimum } 3 \text { years } \\
\text { follow-up }\end{array}$ & $\begin{array}{l}\text { QuickDASH score and percentage of } \\
\text { excellent outcomes were slightly better in } \\
\text { the arthroscopic group }\end{array}$ \\
\hline $\begin{array}{l}\text { Rubenthaler } \\
\text { et al }{ }^{88}\end{array}$ & 2005 & Arthroscopy & 30 & $\begin{array}{l}\text { Open vs } \\
\text { arthroscopic }\end{array}$ & 92 months & $\begin{array}{l}\text { No differences in rating of pain, function, } \\
\text { or complication rate }\end{array}$ \\
\hline Peart et $\mathrm{a}^{89}$ & 2004 & $\begin{array}{l}\text { American Journal of } \\
\text { Orthopedics }\end{array}$ & 87 & $\begin{array}{l}\text { Open vs } \\
\text { arthroscopic }\end{array}$ & $16-22$ months & $\begin{array}{l}\text { No significant difference in outcomes } \\
\text { Patients treated with arthroscopic release } \\
\text { returned to work earlier }\end{array}$ \\
\hline Dunkow et al $\left.\right|^{92}$ & 2004 & $\begin{array}{l}\text { Journal of Bone and } \\
\text { Joint Surgery }\end{array}$ & 45 & $\begin{array}{l}\text { Open vs } \\
\text { percutaneous }\end{array}$ & $\begin{array}{l}\text { Minimum I year } \\
\text { follow-up }\end{array}$ & $\begin{array}{l}\text { Percutaneous group had better patient } \\
\text { satisfaction, time to return to work, } \\
\text { improvements in DASH score, and } \\
\text { improvement in sporting activities }\end{array}$ \\
\hline Szabo et $\mathrm{al}^{94}$ & 2006 & $\begin{array}{l}\text { Journal of Shoulder and } \\
\text { Elbow Surgery }\end{array}$ & 109 & $\begin{array}{l}\text { Open vs } \\
\text { arthroscopic vs } \\
\text { percutaneous }\end{array}$ & 47.8 months & $\begin{array}{l}\text { No differences in recurrences, } \\
\text { complications, and VAS pain scores among } \\
\text { all groups }\end{array}$ \\
\hline Othman ${ }^{93}$ & 2011 & $\begin{array}{l}\text { Archives of Orthopedic } \\
\text { and Trauma Surgery }\end{array}$ & 33 & $\begin{array}{l}\text { Arthroscopic vs } \\
\text { percutaneous }\end{array}$ & $10-12$ months & $\begin{array}{l}\text { Overall no difference in pain relief, } \\
\text { satisfaction, or time to return to work in } \\
\text { both groups }\end{array}$ \\
\hline
\end{tabular}

Abbreviations: DASH, Disabilities of the Arm, Shoulder and Hand; LE, lateral epicondylitis; VAS, visual analog scale. 
or VAS pain scores among all three surgical approaches. ${ }^{94}$ In a review of six studies by Burn et al, the authors found no clinically significant differences among the three surgical approaches. ${ }^{95}$ In contrast, Pierce et al found that open and arthroscopic approaches resulted in higher DASH scores than the percutaneous approach, with no differences in satisfaction or complication rates. ${ }^{96}$ Of note, the open approach was also associated with more postoperative pain and a slightly higher risk of infection. Some of the limitations of these studies include a small population size and lack of randomization. Overall, the current evidence suggests that all three surgical approaches are highly effective in treating LE, and larger RCTs are needed to help delineate any clinically significant differences between approaches.

\section{Summary}

Current evidence suggests that NSAIDs, PT, bracing, and shockwave therapy provide limited benefit in the treatment of chronic LE. Corticosteroid injection, which was initially considered the gold standard treatment, may be effective in the short term but has diminished benefit in the long term, which may be related to structural weakening of the tendon and tenocyte inhibition. ${ }^{97}$ Biologic therapies, including PRP and ABI, have been shown to be more efficacious than steroids for long-term management of LE and have minimal side effects. The early studies on stem cells therapy demonstrate promising results, although comparative studies are needed. Controversy still remains regarding the best surgical approach for the management of LE. Current evidence demonstrates that open, arthroscopic, and percutaneous surgical approaches are all highly effective in treating LE. Arthroscopic and percutaneous approaches may allow for a faster recovery and earlier return to work, although more prospective RCTs and comparative cost analyses are needed.

\section{Disclosure}

The authors report no conflicts of interest in this work.

\section{References}

1. Allander E. Prevalence, Incidence, And Remission Rates of Some Common Rheumatic Diseases Or Syndromes. Scand J Rheumatol. 1974;3(3):145-153.

2. Verhaar JA, Elbow T. Anatomical, epidemiological and therapeutic aspects. Int Orthop. 1994;18(5):263-267.

3. Tarpada SP, Morris MT, Lian J, Rashidi S. Current advances in the treatment of medial and lateral epicondylitis. J Orthop. 2018;15(1):107-110.

4. Sanders Jr TL, Maradit Kremers H, Bryan AJ, Ransom JE, Smith J, Morrey BF. The Epidemiology and Health Care Burden of Tennis Elbow A Population-Based Study. Am J Sports Med. 2015;43(5):1066-1071.

5. Kurppa K, Viikari-Juntura E, Kuosma E, Huuskonen M, Kivi P. Incidence of tenosynovitis or peritendinitis and epicondylitis in a meatprocessing factory. Scand J Work Environ Health. 1991;17(1):32-37.
6. Taylor SA, Hannafin JA. Evaluation and management of elbow tendinopathy. Sports Health. 2012;4(5):384-393.

7. Degen RM, Conti MS, Camp CL, Altchek DW, Dines JS, Werner BC. Epidemiology and Disease Burden of Lateral Epicondylitis in the USA: Analysis of 85,318 Patients. Hss J. 2018;14(1):9-14.

8. Titchener AG, Fakis A, Tambe AA, Smith C, Hubbard RB, Clark DI. Risk factors in lateral epicondylitis (tennis elbow): a case-control study. J Hand Surg Eur Vol. 2013;38(2):159-164.

9. Herquelot E, Bodin J, Roquelaure Y, et al. Work-related risk factors for lateral epicondylitis and other cause of elbow pain in the working population. Am J Ind Med. 2013;56(4):400-409.

10. Buchanan BK, Hughes J. Tennis Elbow (Lateral Epicondylitis). Treasure Island, FL: StatPearls Publishing; 2018.

11. Cohen M, da Rocha Motta Filho G. Lateral epicondylitis of the elbow. Rev Bras Ortop. 2012;47(4):414-420.

12. Richer N, Marchand A-A, Descarreaux M. Management of Chronic Lateral Epicondylitis With Manual Therapy and Local Cryostimulation: A Pilot Study. J Chiropr Med. 2017;16(4):279-288.

13. Nirschl RP, Pettrone FA, Elbow T. The surgical treatment of lateral epicondylitis. J Bone Joint Surg Am. 1979;61(6A):832-839.

14. Nirschl RP, Ashman ES. Elbow tendinopathy: tennis elbow. Clin Sports Med. 2003;22(4):813-836.

15. Thornton SJ, Rogers JR, Prickett WD, Dunn WR, Allen AA, Hannafin JA. Treatment of Recalcitrant Lateral Epicondylitis with Suture Anchor Repair. Am J Sports Med. 2005;33(10):1558-1564.

16. Rompe JD, Overend TJ, Macdermid JC. Validation of the Patient-rated Tennis Elbow Evaluation Questionnaire. J Hand Ther. 2007;20(1):3-11.

17. Haahr JP, Andersen JH. Prognostic factors in lateral epicondylitis: a randomized trial with one-year follow-up in 266 new cases treated with minimal occupational intervention or the usual approach in general practice. Rheumatology. 2003;42(10):1216-1225.

18. Hay EM, Paterson SM, Lewis M, Hosie G, Croft P. Pragmatic randomised controlled trial of local corticosteroid injection and naproxen for treatment of lateral epicondylitis of elbow in primary care. $B M J$. 1999;319(7215):964-968.

19. Boyd HB, Mcleod AC. Tennis elbow. J Bone Joint Surg Am. 1973;55(6):1183-1187.

20. Gregory BP, Wysocki RW, Cohen MS. Controversies in Surgical Management of Recalcitrant Enthesopathy of the Extensor Carpi Radialis Brevis. J Hand Surg Am. 2016;41(8):856-859.

21. Posch JN, Goldberg VM, Larrey R. Extensor fasciotomy for tennis elbow: a long-term follow-up study. Clin Orthop Relat Res. 1978;135:179-182.

22. Knutsen EJ, Calfee RP, Chen RE, Goldfarb CA, Park KW, Osei DA. Factors Associated With Failure of Nonoperative Treatment in Lateral Epicondylitis. Am J Sports Med. 2015;43(9):2133-2137.

23. Pattanittum P, Turner T, Green S, Buchbinder R. Non-steroidal antiinflammatory drugs (NSAIDs) for treating lateral elbow pain in adults. Cochrane Database Syst Rev. 2013;5:CD003686.

24. Park J-Y, Park H-K, Choi J-H, et al. Prospective evaluation of the effectiveness of a home-based program of isometric strengthening exercises: 12-month follow-up. Clin Orthop Surg. 2010;2(3):173-178.

25. Peterson M, Butler S, Eriksson M, Svärdsudd K. A randomized controlled trial of exercise versus wait-list in chronic tennis elbow (lateral epicondylosis). Ups J Med Sci. 2011;116(4):269-279.

26. Coombes BK, Bisset L, Brooks P, Khan A, Vicenzino B. Effect of Corticosteroid Injection, Physiotherapy, or Both on Clinical Outcomes in Patients With Unilateral Lateral Epicondylalgia. JAMA. 2013;309(5):461.

27. Smidt N, van der Windt DAWM, Assendelft WJJ, Devillé WLJM, Korthals-de Bos IBC, Bouter LM. Corticosteroid injections, physiotherapy, or a wait-and-see policy for lateral epicondylitis: a randomised controlled trial. Lancet. 2002;359(9307):657-662.

28. Smidt N, Assendelft WJ, Arola H, et al. Effectiveness of physiotherapy for lateral epicondylitis: a systematic review. Ann Med. 2003;35(1):51-62.

29. Sims SEG, Miller K, Elfar JC, Hammert WC. Non-Surgical Treatment of Lateral Epicondylitis: A systematic Review of Randomized Controlled Trials. HAND. 2014;9(4):419-446. 
30. Struijs PAA, Kerkhoffs GMMJ, Assendelft WJJ, van Dijk CN. Conservative Treatment of Lateral Epicondylitis. Am J Sports Med. 2004;32(2): $462-469$.

31. Luginbühl R, Brunner F, Schneeberger AG. No effect of forearm band and extensor strengthening exercises for the treatment of tennis elbow: a prospective randomised study. Chir Organi Mov. 2008;91(1): $35-40$.

32. Staples MP, Forbes A, Ptasznik R, Gordon J, Buchbinder R. A randomized controlled trial of extracorporeal shock wave therapy for lateral epicondylitis (tennis elbow). J Rheumatol. 2008;35(10):2038-2046.

33. Rompe JD. Extracorporeal shock wave therapy for lateral epicondylitis - a double blind randomized controlled trial" by C. A. Speed, et al. J Orthop Res. 20022003;2021(5):8958-8959.

34. Pettrone FA, Mccall BR. Extracorporeal Shock Wave Therapy without Local Anesthesia for Chronic Lateral Epicondylitis. J Bone Jt Surg. 2005;87(6):1297.

35. Haake M, König IR, Decker T, et al. Extracorporeal shock wave therapy in the treatment of lateral epicondylitis: a randomized multicenter trial. J Bone Joint Surg Am. 2002;84-A(11):1982-1991.

36. Speed CA, Nichols D, Richards C, et al. Extracorporeal shock wave therapy for lateral epicondylitis--a double blind randomised controlled trial. J Orthop Res. 2002;20(5):895-898.

37. Melikyan EY, Shahin E, Miles J, Bainbridge LC. Extracorporeal shockwave treatment for tennis elbow. A randomised double-blind study. J Bone Joint Surg Br. 2003;85(6):852-855.

38. Chung B, Wiley JP, Rose MS. Long-term effectiveness of extracorporeal shockwave therapy in the treatment of previously untreated lateral epicondylitis. Clin J Sport Med. 2005;15(5):305-312.

39. Verhaar JA, Walenkamp GH, van Mameren H, Kester AD, van der Linden AJ. Local corticosteroid injection versus Cyriax-type physiotherapy for tennis elbow. J Bone Joint Surg Br. 1996;78(1):128-132.

40. Krogh TP, Bartels EM, Ellingsen T, et al. Comparative Effectiveness of Injection Therapies in Lateral Epicondylitis. Am J Sports Med. 2013;41(6): 1435-1446

41. Bisset L, Beller E, Jull G, Brooks P, Darnell R, Vicenzino B. Mobilisation with movement and exercise, corticosteroid injection, or wait and see for tennis elbow: randomised trial. BMJ. 2006;333(7575):939.

42. Newcomer KL, Laskowski ER, Idank DM, Mclean TJ, Egan KS. Corticosteroid injection in early treatment of lateral epicondylitis. Clin J Sport Med. 2001;11(4):214-222.

43. Lindenhovius A, Henket M, Gilligan BP, Lozano-Calderon S, Jupiter JB, Ring D. Injection of Dexamethasone Versus Placebo for Lateral Elbow Pain: A Prospective, Double-Blind, Randomized Clinical Trial. J Hand Surg Am. 2008;33(6):909-919.

44. Osborne H. Stop injecting corticosteroid into patients with tennis elbow, they are much more likely to get better by themselves! J Sci Med Sport. 2010;13(4):380-381.

45. Scott A, Khan KM. Corticosteroids: short-term gain for long-term pain? Lancet. 2010;376(9754):1714-1715.

46. Kahlenberg CA, Knesek M, Terry MA. New Developments in the Use of Biologics and Other Modalities in the Management of Lateral Epicondylitis. Biomed Res Int. 2015;2015(5):439309.

47. Galatz LM, Gerstenfeld L, Heber-Katz E, Rodeo SA. Tendon regeneration and scar formation: The concept of scarless healing. J Orthop Res. 2015;33(6):823-831.

48. Seetharamaiah V, Gantaguru A, Basavarajanna S. A comparative study to evaluate the efficacy of platelet-rich plasma and triamcinolone to treat tennis elbow. Indian J Orthop. 2017;51(3):304.

49. Montalvan B, Le Goux P, Klouche S, Borgel D, Hardy P, Breban M. Inefficacy of ultrasound-guided local injections of autologous conditioned plasma for recent epicondylitis: results of a double-blind placebo-controlled randomized clinical trial with one-year follow-up. Rheumatology. 2016;55(2):279-285.

50. Palacio EP, Schiavetti RR, Kanematsu M, Ikeda TM, Mizobuchi RR, Galbiatti JA. Effects of platelet-rich plasma on lateral epicondylitis of the elbow: prospective randomized controlled trial. Rev Bras Ortop. 2016;51(1):90-95.
51. Behera P, Dhillon M, Aggarwal S, Marwaha N, Prakash M. LeukocytePoor Platelet-Rich Plasma versus Bupivacaine for Recalcitrant Lateral Epicondylar Tendinopathy. J Orthop Surg. 2015;23(1):6-10.

52. Gautam VK, Verma S, Batra S, Bhatnagar N, Arora S. Platelet-Rich Plasma versus Corticosteroid Injection for Recalcitrant Lateral Epicondylitis: Clinical and Ultrasonographic Evaluation. J Orthop Surg. 2015;23(1):1-5.

53. Lebiedziński R, Synder M, Buchcic P, Polguj M, Grzegorzewski A, Sibiński M. A randomized study of autologous conditioned plasma and steroid injections in the treatment of lateral epicondylitis. Int Orthop. 2015;39(11):2199-2203.

54. Tetschke E, Rudolf M, Lohmann CH, Stärke C. Autologous Proliferative Therapies in Recalcitrant Lateral Epicondylitis. Am J Phys Med Rehabil. 2015;94(9):696-706.

55. Yadav R, Kothari SY, Borah D. Comparison of Local Injection of Platelet Rich Plasma and Corticosteroids in the Treatment of Lateral Epicondylitis of Humerus. J Clin Diagn Res. 2015;9(7):RC05-RC07.

56. Mishra AK, Skrepnik NV, Edwards SG, et al. Efficacy of Platelet-Rich Plasma for Chronic Tennis Elbow. Am J Sports Med. 2014;42(2):463-471.

57. Raeissadat SA, Rayegani SM, Hassanabadi H, Rahimi R, Sedighipour L, Rostami K. Is Platelet-rich plasma superior to whole blood in the management of chronic tennis elbow: one year randomized clinical trial. BMC Sports Sci Med Rehabil. 2014;6(1):12.

58. Raeissadat SA, Sedighipour L, Rayegani SM, Bahrami MH, Bayat M, Rahimi R. Effect of Platelet-Rich Plasma (PRP) versus Autologous Whole Blood on Pain and Function Improvement in Tennis Elbow: A Randomized Clinical Trial. Pain Res Treat. 2014;2014:191525.

59. Omar AS, Ibrahim ME, Ahmed AS, Said M. Local injection of autologous platelet rich plasma and corticosteroid in treatment of lateral epicondylitis and plantar fasciitis: Randomized clinical trial. Egypt Rheumatol. 2012;34(2):43-49.

60. Creaney L, Wallace A, Curtis M, Connell D. Growth factor-based therapies provide additional benefit beyond physical therapy in resistant elbow tendinopathy: a prospective, single-blind, randomised trial of autologous blood injections versus platelet-rich plasma injections. $\mathrm{Br}$ J Sports Med. 2011;45(12):966-971.

61. Gosens T, Peerbooms JC, van Laar W, den Oudsten BL. Ongoing Positive Effect of Platelet-Rich Plasma Versus Corticosteroid Injection in Lateral Epicondylitis. Am J Sports Med. 2011;39(6):1200-1208.

62. Thanasas C, Papadimitriou G, Charalambidis C, Paraskevopoulos I, Papanikolaou A. Platelet-Rich Plasma Versus Autologous Whole Blood for the Treatment of Chronic Lateral Elbow Epicondylitis. Am J Sports Med. 2011;39(10):2130-2134.

63. Peerbooms JC, Sluimer J, Bruijn DJ, Gosens T. Positive Effect of an Autologous Platelet Concentrate in Lateral Epicondylitis in a Double-Blind Randomized Controlled Trial. Am J Sports Med. 2010;38(2):255-262.

64. Chen X, Jones IA, Park C, Vangsness CT. The Efficacy of Platelet-Rich Plasma on Tendon and Ligament Healing: A Systematic Review and Metaanalysis With Bias Assessment. Am J Sports Med. 2017;036354651774374.

65. de Vos R-J, Windt J, Weir A. Strong evidence against platelet-rich plasma injections for chronic lateral epicondylar tendinopathy: a systematic review. Br J Sports Med. 2014;48(12):952-956.

66. Mishra AK, Skrepnik N V, Edwards SG, et al. Efficacy of Platelet-Rich Plasma for Chronic Tennis Elbow A Double-Blind, Prospective, Multicenter, Randomized Controlled Trial of 230 Patients. Am J Sports Med. 2014;42(2):463-471.

67. Ben-Nafa W, Munro W. The effect of corticosteroid versus platelet-rich plasma injection therapies for the management of lateral epicondylitis: A systematic review. SICOT J. 2018;4(7):11.

68. Hastie G, Soufi M, Wilson J, Roy B. Platelet rich plasma injections for lateral epicondylitis of the elbow reduce the need for surgical intervention. J Orthop. 2018;15(1):239-241.

69. Merolla G, Dellabiancia F, Ricci A, et al. Arthroscopic Debridement Versus Platelet-Rich Plasma Injection: A Prospective, Randomized, Comparative Study of Chronic Lateral Epicondylitis With a Nearly 2-Year Follow-Up. Arthroscopy. 2017;33(7):1320-1329. 
70. Mazzocca AD, Mccarthy MB, Chowaniec DM, et al. Platelet-rich plasma differs according to preparation method and human variability. $J$ Bone Joint Surg Am. 2012;94(4):308-316.

71. Calandruccio JH, Steiner MM. Autologous Blood and Platelet-Rich Plasma Injections for Treatment of Lateral Epicondylitis. Orthop Clin North Am. 2017;48(3):351-357.

72. Mishra A, Randelli P, Barr C, Talamonti T, Ragone V, Cabitza P. PlateletRich Plasma and the Upper Extremity. Hand Clin. 2012;28(4):481-491.

73. Chou LC, Liou TH, Kuan YC, Huang YH, Chen HC. Autologous blood injection for treatment of lateral epicondylosis: A meta-analysis of randomized controlled trials. Phys Ther Sport. 2016;18:68-73.

74. Lee SY, Kim W, Lim C, Chung SG. Treatment of Lateral Epicondylosis by Using Allogeneic Adipose-Derived Mesenchymal Stem Cells: A Pilot Study. Stem Cells. 2015;33(10):2995-3005.

75. Connell D, Datir A, Alyas F, Curtis M. Treatment of lateral epicondylitis using skin-derived tenocyte-like cells. Br J Sports Med. 2009;43(4):293-298.

76. Wang A, Breidahl W, Mackie KE, et al. Autologous Tenocyte Injection for the Treatment of Severe, Chronic Resistant Lateral Epicondylitis. Am J Sports Med. 2013;41(12):2925-2932.

77. Singh A, Gangwar DS, Singh S. Bone marrow injection: A novel treatment for tennis elbow. J Nat Sci Biol Med. 2014;5(2):389-391.

78. Wang D, Degen RM, Camp CL, Mcgraw MH, Altchek DW, Dines JS. Trends in Surgical Practices for Lateral Epicondylitis Among Newly Trained Orthopaedic Surgeons. Orthop J Sports Med. 2017;5(10): 2325967117730570

79. Balk ML, Hagberg WC, Buterbaugh GA, Imbriglia JE. Outcome of surgery for lateral epicondylitis (tennis elbow): effect of worker's compensation. Am J Orthop. 2005; 34(3):122-126.

80. Barth J, Mahieu P, Hollevoet N. Extensor tendon and fascia sectioning of extensors at the musculotendinous unit in lateral epicondylitis. Acta Orthop Belg. 2013;79(3):266-270.

81. Dunn JH, Kim JJ, Davis L, Nirschl RP. Ten- to 14-Year Follow-up of the Nirschl Surgical Technique for Lateral Epicondylitis. Am J Sports Med. 2008;36(2):261-266.

82. Dwyer AJ, Govindaswamy R, Elbouni T, Chambler AFW. Are "knife and fork" good enough for day case surgery of resistant tennis elbow? Int Orthop. 2010;34(1):57-61

83. Thornton SJ, Rogers JR, Prickett WD, Dunn WR, Allen AA, Hannafin JA. Treatment of Recalcitrant Lateral Epicondylitis with Suture Anchor Repair. Am J Sports Med. 2005;33(10):1558-1564.
84. Kroslak M, Murrell GAC. Surgical Treatment of Lateral Epicondylitis. Orthop J Sports Med. 2017;5(Suppl 3):2325967117S0012.

85. Baker CL, Murphy KP, Gottlob CA, Curd DT. Arthroscopic classification and treatment of lateral epicondylitis: two-year clinical results. $J$ Shoulder Elbow Surg. 2000;9(6):475-482.

86. Kwon BC, Kim JY, Park KT. The Nirschl procedure versus arthroscopic extensor carpi radialis brevis débridement for lateral epicondylitis. $J$ Shoulder Elbow Surg. 2017;26(1):118-124.

87. Solheim E, Hegna J, Øyen J. Arthroscopic versus open tennis elbow release: 3- to 6-year results of a case-control series of 305 elbows. Arthroscopy. 2013;29(5):854-859.

88. Rubenthaler F, Wiese M, Senge A, Keller L, Wittenberg RH. Long-term follow-up of open and endoscopic Hohmann procedures for lateral epicondylitis. Arthroscopy. 2005;21(6):684-690.

89. Peart RE, Strickler SS, Schweitzer KM. Lateral epicondylitis: a comparative study of open and arthroscopic lateral release. Am J Orthop. 2004;33(11):565-567.

90. Karkhanis S, Frost A, Maffulli N. Operative management of tennis elbow: a quantitative review. Br Med Bull. 2008;88(1):171-188.

91. Grundberg AB, Dobson JF. Percutaneous release of the common extensor origin for tennis elbow. Clin Orthop Relat Res. 2000;376: 137-140.

92. Dunkow PD, Jatti M, Muddu BN. A comparison of open and percutaneous techniques in the surgical treatment of tennis elbow. J Bone Joint Surg Br. 2004;86(5):701-704.

93. Othman AMA. Arthroscopic versus percutaneous release of common extensor origin for treatment of chronic tennis elbow. Arch Orthop Trauma Surg. 2011;131(3):383-388.

94. Szabo SJ, Savoie FH, Field LD, Ramsey JR, Hosemann CD. Tendinosis of the extensor carpi radialis brevis: an evaluation of three methods of operative treatment. J Shoulder Elbow Surg. 2006;15(6):721-727.

95. Burn MB, Mitchell RJ, Liberman SR, Lintner DM, Harris JD, Mcculloch PC. Open, Arthroscopic, and Percutaneous Surgical Treatment of Lateral Epicondylitis. HAND. Epub 2017 March 1.

96. Pierce TP, Issa K, Gilbert BT, et al. A Systematic Review of Tennis Elbow Surgery: Open Versus Arthroscopic Versus Percutaneous Release of the Common Extensor Origin. Arthroscopy. 2017;33(6): 1260-1268.

97. Scutt N, Rolf CG, Scutt A. Glucocorticoids inhibit tenocyte proliferation and Tendon progenitor cell recruitment. J Orthop Res. 2006;24(2):173-182.
Open Access Journal of Sports Medicine

\section{Publish your work in this journal}

The Open Access Journal of Sports Medicine is an international peer-reviewed, open access journal publishing original research, reports, reviews and commentaries on all areas of sports medicine. The journal is included on PubMed. The manuscript management system is completely online and includes a very quick and fair

\section{Dovepress}

peer-review system. Visit http://www.dovepress.com/testimonials.php to read real quotes from published authors. 